\title{
Anxiety in a digitalised work environment
}

\author{
Katharina F. Pfaffinger ${ }^{1}$ Julia A. M. Reif ${ }^{1}$ - Erika Spieß ${ }^{1} \cdot$ Rita Berger $^{2}$
}

Published online: 29 January 2020

(c) The Author(s) 2020

\begin{abstract}
This article in the journal Gruppe. Interaktion. Organisation. (GIO) presents a qualitative study which aims at conceptualising digitalisation anxiety. The increasing spread of digital technologies has consequences for how we live, work, and communicate. Alongside positive opportunities, digitalisation also involves risks and can lead to negative reactions such as anxiety. We conducted 26 interviews examining the psychological roots of digitalisation anxiety. We found that the digitalisation megatrend evokes anxieties related not only to individual or organisational changes, but also broader societal considerations. Based on our results, we suggest interventions that could help organisations, teams, and individuals cope with the triggers of digitalisation anxiety in order to improve people's feelings and experiences related to digitalisation.
\end{abstract}

Keywords Digitalisation · Digitalisation anxiety $\cdot$ Qualitative interviews

\section{Angst in einer digitalisierten Arbeitswelt}

\section{Zusammenfassung}

Dieser Beitrag der Zeitschrift Gruppe. Interaktion. Organisation. (GIO) stellt eine qualitative Studie zur Konzeptualisierung von Digitalisierungsangst vor. Die zunehmende Verbreitung digitaler Technologien hat Auswirkungen darauf wie wir leben, arbeiten und miteinander kommunizieren. Neben den positiven Möglichkeiten und Chancen bringt die Digitalisierung auch Risiken und negative Reaktionen wie Angst mit sich. Um die psychologischen Ursachen dieser so genannten Digitalisierungsangst zu analysieren, führten wir 26 Interviews durch. Wir fanden heraus, dass der Megatrend zur Digitalisierung nicht nur Angst in Bezug auf individuelle oder organisationale Veränderungen, sondern auch im Hinblick auf gesellschaftliche Aspekte mit sich bringt. Basierend auf unseren Ergebnissen schlagen wir Interventionen vor, die Organisationen, Teams und Individuen dabei helfen können, mit den Auslösern von digitaler Angst umzugehen, um die Gefühle und Erfahrungen von Individuen in Bezug auf Digitalisierung zu verbessern.

Schlüsselwörter Digitalisierung · Digitalisierungsangst · Qualitative Interviews

Some ideas described in this paper were presented at the 51th Congress of the German Psychological Society (DGPs) in Frankfurt am Main, Germany.

This research was part of the Erasmus + Knowledge Alliances Project "IMPRESS-Improving management competences on Excellence based Stress avoidance and working towards Sustainable organisational development in Europe" (Project Reference: 588315-EPP-1-2017-1-ES-EPPKA2-KA). Disclaimer: The European Commission's support for the production of this publication does not constitute an endorsement of the contents, which reflect the views only of the authors, and the Commission cannot be held responsible for any use which may be made of the information contained therein.

Katharina F. Pfaffinger

katharina.pfaffinger@psy.lmu.de

1 Economic and Organizational Psychology, Ludwig-Maximilians-Universitaet Muenchen, Leopoldstraße 13, 80802 Munich, Germany

2 Department of Social Psychology, Facultad de Psicología, Universidad de Barcelona, Barcelona, Spain 


\section{Introduction}

Digitalisation represents "the integration of multiple technologies into all aspects of daily life that can be digitized" (Gray and Rumpe 2015, p. 1319). In 2015, about 20 billion devices were connected online worldwide. Forecasts suggest that this number will increase to half a trillion by 2030 (Althaus et al. 2018). New forms of payment (contactless or mobile payment), internet of things (defined as digital interconnectedness of machines/buildings), smart homes (e.g., automated regulation of blinds depending on weather and light conditions), smart mobility (e.g., automated traffic management based on air quality), or e-healthcare (e.g., digital patient files, telemedicine) are just a few examples of how digitalisation has penetrated many areas of private, public and working life (Benevolo et al. 2016; Federal Ministry for Economic Affairs and Energy 2018; Federal Ministry of Health 2018; Gray and Rumpe 2015).

Digitalisation is associated with high levels of uncertainty as it is not clear what will change, how it will change and when those changes will happen. A recent study by Kirchner (2019) on perceptions of digitalisation in Germany revealed that nearly $40 \%$ of survey respondents representative for the population felt unsure about and left behind by digitalisation. Uncertainties resulting from external or environmental factors can lead to anxiety (Cambre and Cook 1985). Anxiety can be defined as "characteristic symptom of modern times, including the pressure for social change produced by rapid scientific and technological advances" (May 1950; quoted in Cambre and Cook 1985 , p. 38) and can have negative behavioural consequences such as impeded performance, avoidance or impaired interactions (Heerey and Kring 2007; Marcoulides 1988; Torkzadeh and Angulo 1992).

In this vein, we define anxiety in a digitalised and digitalising environment, which we term digitalisation anxiety, as feelings of tension and discomfort with respect to the emergence of new technologies and the integration of those technologies in all aspects of daily life, which changes the way information is presented and processed and thus how people communicate, work and live (see also Berger et al. 2016, p. 0391; Salanova et al. 2007). As such, digitalisation anxiety not only refers to a specific technology, but covers a broader range of feelings, technologies as well as the process of the technologies' penetration into and permeation of daily life. Integrating a process perspective and a content perspective, digitalisation anxiety therefore distinguishes from related concepts, such as technostress, which refers to "stress experienced by end users of Information and Communication Technologies (ICTs)" (Ragu-Nathan et al. 2008, p. 417), computer anxiety, which is defined as an "anxiety state in that the emotional reactions fluctuate according to the presence (real or anticipated) or absence of a computer" (Raub 1981, p. 10) or technophobia, which is defined as "fear, dislike or discomfort by using modern technologies and complex technical devices (especially computers)" (Osiceanu 2015, p. 1139). All these concepts target at the (anticipated) use or presence of specific forms of technology or technology in general but do not include the process of their integration in all aspects of daily life and the consequences of this integration.

Research has shown that stress and anxiety related to technology can have negative effects on individual and organisational outcomes: For example, technostress results in perceived work overload, demoralized and frustrated users, information fatigue, loss of motivation, dissatisfaction at work, decreased organisational and continuance commitment, decreased individual productivity and increased role stress (Brod 1984; Ragu-Nathan et al. 2008; Tarafdar et al. 2007). Technology anxiety negatively influences role clarity, motivation, and perceived ability (Meuter et al. 2005) and can significantly influence the acceptance of newly introduced systems (Kummer et al. 2017).

Due to the severe consequences of digitalisation-related stress and anxiety on health, well-being, and organisational outcomes, it is necessary to better understand the psychological roots, triggers, and organisational manifestations of digitalisation anxiety, which goes beyond existing concepts by referring not only to the use of new technologies but also to the process of their integration in many aspects of life. Hence, we empirically investigated the following research questions: How do employees feel about the digitalisation of the work environment and (if they associate it with anxiety), what are triggers for digitalisation anxiety? Due to the exploratory nature of our research, we applied a qualitative research approach which will be introduced in the following paragraph.

\section{Methods}

Sampling procedure. Following Robinson's (2014) fourpoint approach to qualitative sampling, we first defined the target population. As we wished to assess work-related stress and negative feelings, being employed was specified as an inclusion criterion. Following the exploratory approach, we targeted a heterogeneous sample. Second, we determined the minimum sample size. Recommendations range from 3 to 25 participants for qualitative interview studies examining people's experiences or exploring a topic for purposes such as generating items for a scale (Sandelowski 1995; Smith et al. 2009). Third, we chose a sampling strategy. We applied convenience sampling and selected interviewees who were convenient to reach and willing to take part in the study. They were included in the sample on a first-come-first-served basis (Robinson 
2014). As the study was part of a broader research project, several project partners were involved in data collection. We recruited interviewees through different sources (using project partners' contacts as well as personal contacts) and included people from different industries and educational backgrounds in our sample in order to ensure generalizability. Fourth, we informed all interviewees about their rights and the voluntary nature of their participation, the general topic of the study, and the interview structure in order to ensure informed consent. Interviewees were not compensated for taking part in the interviews.

Sample. An international consortium of ten project partners ${ }^{1}$ conducted 26 qualitative interviews (male: $n=13$, female: $n=11$, no gender indicated: $n=2$, Mean age $=43.1$ years, no age indicated: $n=2$ ). To ensure a common standard, we gave all interviewers detailed instructions for data collection. Interviewees, who were personally recruited to participate in the study by the project partners, worked in different sectors (the public sector, healthcare, banking, consulting, the industrial sector) and had different amounts of work experiences and employment durations (indicated durations ranged between 3 and 40 years). All of the interviewees used some kind of digital tools in their everyday work (e.g., computer systems, virtual communication tools, digital service products, or programs such as SAP) and therefore were affected by digitalisation. Some were directly involved in strategic decisions concerning digital transformation and some worked in consulting other companies on digitalisation issues.

Data collection. We conducted semi-structured interviews focused on the interviewees' experiences and feelings with regard to digitalisation. We prepared an interview guide to ensure that we asked the same questions in the same order in each interview.

The interview guide consisted of the following main questions ${ }^{2}$ :

1. Do you feel optimistic or pessimistic about digitalisation?

\footnotetext{
1 This research is part of the Erasmus+ Project Impress ("Improving management competences on Excellence based Stress avoidance and working towards Sustainable organisational development in Europe"). The project aims to develop and validate an innovative toolset for identifying and dealing with stress-related issues in organisations and to provide support by means of new coaching and training materials addressing the identified problems.

2 Additional questions about personal experiences, digitalisation as a motivator and stressor, reasons for positive feelings about digitalisation and expectations about the future workplace were also part of the interview guide but will not be reported in this article.
}

2. To what extent does digitalisation of the work environment cause you happiness/anxiety? If anxiety is mentioned: Why do you feel anxious about digitalisation?

Interviews were conducted in German $(n=18)$, English $(n=6)$, and Spanish $(n=2)$. One of the study authors with deep knowledge of both languages translated the Spanish interviews into English. The interviews lasted $35.29 \mathrm{~min}$ utes on average (Min $=19.73$ minutes, Max $=75$ minutes, in 8 cases the length of the interview was not specified). The interviews took place between January and March 2018.

Data analysis. Data analysis was conducted in English and German and finally translated into English in cooperation with a native speaker. We recorded the interviews, transcribed them according to rules formulated by Kuckartz et al. (2008), and conducted a qualitative content analysis following Mayring and Fenzl (2014): We identified units of meaning, paraphrased them and classified them into inductively generated categories. As the analysis progressed, we summarized the categories into more abstract, interpretative axial codes (see results).

In order to ensure objectivity in the data analysis, the interviews were coded by two raters and Cohen's Kappa was calculated as a measure for interrater reliability. Cohen's Kappa was acceptable for Question $1(K=0.93)$, and, after a further round of discussing and refining the identified categories, excellent for Question $2(K=1.00)$.

\section{Results}

\subsection{Do people feel optimistic or pessimistic about digitalisation?}

We examined the interviewees' overall attitudes by combining their answers to the first question into an overall attitude code, which was either positive (interviewee gave only optimistic answers), negative (interviewee gave only pessimistic answers), or ambivalent (interviewee gave both optimistic and pessimistic answers): eleven interviewees were generally optimistic (e.g., "I feel optimistic about the digitalisation of the work environment", \#5, line 101), five were generally pessimistic (e.g., "Personally, I am rather pessimistic", \#18, line 277), six were ambivalent (e.g., "In my opinion it is hard to say everything is very good or I think it is all bad", \#24, lines $211 \mathrm{f}$.) and four interviewees did not provide an answer to this question. 
Table 1 Triggers of digitalisation anxiety

\begin{tabular}{lll}
\hline Societal triggers & Organisational triggers & Individual triggers \\
\hline Consequences of digitalisation & Organisations' expectations & Personal development \\
- Lack of predictability & - Constant availability & - Lack of time for training \\
- Job insecurity & - Quick understanding of new processes & - Internal pressure to under- \\
- Reduced amount of work & - Taking part in trainings & stand developments \\
- Social exclusion & - Quick implementation of new technologies & Lack of technological affinity \\
Stressful digitalisation process & Organisational structure & Changes in work \\
- Stressful initial phase of digitalisation & - Lack of organisational infrastructure & - Increased speed of work \\
- Challenge to keep up with developments & - Lack of user-friendly, individually supportive IT & - Loss of individual control \\
Surveillance & systems & Individual communication prob- \\
Concerns about data usage & - Inexperienced people in powerful positions & lems \\
Technologisation & Technical issues & \\
- Dependency on technology & - Vulnerability to hacker attacks & \\
- Robotisation of humans & - Technical problems & \\
- Work routines controlled by machines & & \\
\hline
\end{tabular}

\subsection{Why do people feel anxious about digitalisation?}

To identify triggers of digitalisation anxiety, we asked the interviewees about the extent to which the digitalisation of the work environment caused them happiness/anxiety. Nineteen interviewees talked about anxieties related to digitalisation and were subsequently asked why they felt anxious about the digitalisation of the work environment. Interviewees answered this question on different levels of abstraction, which we categorized as society, organisation and individual. Table 1 provides an overview of what was mentioned on each level.

We also assessed whether each interviewee mentioned digitalisation anxiety triggers on one, two or three levels. The majority only mentioned triggers on one $(n=10)$ or two levels $(n=8)$; just one interviewee named triggers on all three levels.

Societal triggers of digitalisation anxiety. Interviewees most frequently described being afraid of the general impact of digitalisation on society ( $n=22$ statements). They mentioned the consequences of digitalisation: the lack of predictability in the effects of digitalisation on society, job insecurity resulting from ongoing automatization, and a decrease in the total amount of available work (e.g., "I have a critical view because it is always stated that many new jobs are created due to digitalisation. But more and more jobs are disappearing as well. And I am of the opinion that digitalisation cannot completely compensate for those jobs" \#21, lines $280 \mathrm{ff}$.). Interviewees also talked about social exclusion as a further trigger of anxiety, which refers to the risk that people may become isolated from society if they are no longer able to participate in the digitalised world (e.g., "The anxiety is not directly caused by technology itself but by society. By the fact that one might drop out of the part of society which participates [in digitalisation]",
\#12, lines $239 \mathrm{ff}$.). Moreover, strain related to the process of digitalisation was brought up as a trigger. Specifically, strain related to the initial implementation phase of new technologies as well as the ongoing challenge of keeping up with the latest developments were mentioned (e.g., "For many people the 'comfort zone' gets lost due to the challenge of keeping up to date", \#7, line 92). Furthermore, interviewees mentioned feelings of being monitored in the sense of general behavioural surveillance (e.g., by facial recognition systems).

Concerns about data usage were another anxiety trigger mentioned by the interviewees (e.g., "Understanding how much data is generated and processed by Industry $4.0^{3}$ I am a bit nervous about what happens to all this data", \#8, lines $48 \mathrm{f}$.). Other societal triggers were related to technologisation itself. Interviewees mentioned an increasing dependency on technology. They mentioned the robotisation of humans, i.e., the fear that humans will become more and more similar to robots as a result of the ongoing automatization of processes and workflows. Interviewees also named the control of everyday work routines by machines as a trigger for anxiety (e.g., "[...] Thinking about my whole working day being regulated by a machine [...] seems very strange to me", \#16, lines 247f.).

Organisational triggers of digitalisation anxiety. Interviewees also mentioned triggers of digitalisation anxiety that were related to and can be controlled by organisations ( $n=11$ statements). They mentioned organisations' expectations, which mainly referred to the expectation that employees be constantly available for work duties even after the official end of the workday due to new technologies such as smartphones. Organisations also expected

\footnotetext{
${ }^{3}$ Industry 4.0 is a term which describes "the use of digital technologies in the manufacturing process to produce higher-quality goods at reduced costs" (Statista 2019, p. 2).
} 
them to be able to quickly understand new processes and technologies and to participate in trainings. Additionally, organisations often expected new technologies to be implemented unreasonably quickly and underestimated the time necessary for their introduction. Interviewees also described organisational structures as triggers for anxiety, specifically the lack of an organisational support infrastructure to help employees deal with technical issues, e.g. an IT helpdesk (e.g., "Sadly, in my company [...] supporting infrastructure like technical equipment, ICT tools etc. have not been provided", \#3, lines $26 \mathrm{f}$.).

A further trigger was the lack of user-friendly IT systems and applications that could individually support employees in getting their work done. They mentioned how IT experts without leadership experience and a broader organisational perspective could reach high-level positions due to the increasing importance of IT in organisations. Interviewees identified technical issues on the organisational level as a further trigger for anxiety. First, organisations' vulnerability to becoming victims of hacker attacks was named (e.g., "If you see how computers are locked by a virus and you sometimes need to pay ransom money. It is not funny when whole companies are paralysed, if nothing works anymore and the server is down. You depend on those systems and cannot do anything anymore", \#26, lines $408 \mathrm{ff}$.). According to the interviewees, organisations often do not take preventive security measures as they underestimate the risk of being attacked. However, when an attack does take place, the implications can be quite dramatic, ranging from an inability to work for several days to data loss. Second, technical problems with programs or systems used in the organisations were mentioned as a further trigger for digitalisation anxiety.

Individual triggers of digitalisation anxiety. Interviewees also stated intrapersonal factors as triggers of digitalisation anxiety ( $n=9$ statements). They described issues concerning their personal development, such as a lack of time for trainings necessary to keep up with technological innovations at work. Interviewees also described an internal pressure to comprehend new technological developments, which is often difficult due to the increasing complexity of new systems (e.g., "[...] I often do not have time to check for new relevant training content on the company intranet and study the courses", \#7, lines $92 \mathrm{ff}$.). Comprehending new technology is even more difficult if employees lack technological affinity, which was described as a further trigger of anxiety.

Furthermore, interviewees described how digitalisation caused changes in their work, which in turn led to feelings of anxiety: Some interviewees mentioned how the speed of work is generally increasing due to factors such as higherspeed communication and clients' or colleagues' expecta- tions of immediate answers (e.g., "The client sends documents or information and rapidly expects an answer", \#13, p. 74). Some interviewees mentioned a decreasing ability to individually control their own work procedures, as multiple monitoring processes need to be followed. At the same time, opportunities for individual flexibility in how to complete one's tasks are declining. Interviewees also reported communication problems resulting from changes in communication methods, the increasing number of technology-supported communication channels and associated challenges in finding the right balance between digital and personal communication. They mentioned concerns about the efficiency of digital communication in specific situations, the risk of misunderstandings, and the difficulty of choosing the right channels in specific situations (e.g., "People don't meet each other face to face but instead have meetings over Skype. I feel that this is not the most efficient way of communication", \#4, lines $49 \mathrm{ff}$.).

\section{Discussion}

We qualitatively investigated employees' feelings about digitalisation and triggers for digitalisation anxiety. Digitalisation of the work environment evoked mixed feelings: while about $50 \%$ of interviewees expressed positive feelings, $50 \%$ had negative or ambivalent feelings. Interviewees most often mentioned digitalisation anxiety triggers on the societal level, where they associated digitalisation with unpredictable consequences for living and working within society. On the organisational level, digitalisation mainly caused anxiety due to rising organisational expectations for employees. On the individual level, employees feared that digitalisation goes along with self-imposed pressure and a perceived loss of personal control.

Triggers on the societal level were more often mentioned than triggers on the organisational or individual level. One explanation for this finding could be the interview partners' decreasing amount of control in handling anxiety triggers as one moves from the individual to the organisational and finally the societal level. According to the Job DemandsControl Model (Karasek 1979, 2011), mental strain results from an interaction of high demands (e.g., workload) and low control. Job control is defined as the level of decision latitude employees have in how to meet demands. This decision latitude is low for societal triggers, as they often depend on political or legal institutions, with individuals therefore having very limited control. Organisational and individual anxiety triggers, by contrast, were described more tangibly and might be more susceptible to individual control which makes them easier targets for interventions.

Most triggers mentioned by interviewees were related to uncertainty: Not knowing what happens to one's data, or 
what consequences digitalisation will have for the job market and for society in general resulted in negative feelings and digitalisation anxiety. Previous research has also shown that uncertainty is related to anxiety in the work environment (e.g., Marks and Mirvis 1997). Reducing uncertainty thus seems to be a key starting point for designing practical interventions to reduce digitalisation anxiety (see practical implications).

Interviewees often mentioned anxieties related to job insecurity as a result of digitalisation. An analysis by PricewaterhouseCoopers LLP (2018) states that about $37 \%$ of jobs in Germany are at high risk for potential automation by the 2030s. In particular, jobs for workers with low or medium levels of education are at a higher risk of being automated than jobs for highly educated workers. Thus, for workers with low or medium levels of education, concerns regarding job insecurity seem to be justified. However, there will not only be job cuts but also opportunities for new types of jobs, especially in the IT sector. This is why some researchers speak of shifting roles rather than a decrease in the number of jobs (Statista 2019).

Consequently, digitalisation anxieties could serve as a motivation to proactively search for training opportunities to qualify for jobs requiring higher levels of education and skills.

\subsection{Theoretical implications}

Our results showed that digitalisation anxiety is a prevalent phenomenon that goes beyond previous conceptualisations such as technostress (Ragu-Nathan et al. 2008), computer anxiety (Raub 1981), technostrain (Salanova et al. 2013, 2014), or technophobia (Osiceanu 2015) which primarily focus on information and communication technologies or technical devices themselves as the roots of strain and anxiety and not the process of their integration into daily life. Although some of our results are in line with Ragu-Nathan et al.'s (2008) findings regarding techno-overload (e.g., higher pace and amount of work), techno-invasion (e.g., blurring spatial and temporal boundaries of work), techno-complexity (e.g., lack of knowledge about technology), techno-insecurity (e.g., threats to job security), and techno-uncertainty (e.g., constant changes), we show that digitalisation anxiety also arises from societal triggers. The societal triggers identified in our study offer new insights into Ragu-Nathan et al.'s (2008) techno-uncertainty category, as they describe reasons for anxiety related to the integration of digitalisation in the way we work and live in society. Our results also identify new uncertainty-related stressors concerning the societal consequences of digitalisation (e.g., reduced amount of work due to automatization, risk of social exclusion, fear of surveillance). Those societal triggers have not been included sufficiently in previous concepts such as technostress, computer anxiety, or technology anxiety. Furthermore, our results point to additional stressors on the organisational (e.g., vulnerability to hacker attacks and technical problems) and individual levels (e.g., loss of control and communication problems).

Additionally, many existing scales were developed between the 1980s and 2010s (e.g., computer anxiety defined by Raub (1981) or technostress defined by Ragu-Nathan et al. (2008)) and need to be updated due to the technological advances, which create new forms of human-technology interaction such as living in a smart home or paying contactless which also should be taken into account when conceptualising people's digitalisation-related concerns and anxieties. We can also infer from the interviews that anxiety is not only related to the (anticipated) use of technologies but also to the integration (process) of those technologies in many aspects of life. As digitalisation is an ongoing process and not just an "item" or one-time event, it is crucial to also take a process perspective which is missing in previous concepts referring only to specific "items" such as computers or technology in general. These findings demonstrate the need for the concept digitalisation anxiety and a corresponding updated measure (Pfaffinger et al. 2019).

In addition to the integrative character of the concept by combining a content with a process view, digitalisation anxiety could also serve as integrative concept explaining various societal phenomena related to digitalisation such as participation in demonstrations related to digitalisation, the creation of new digitalisation-related laws, or the success or failure of implementing new IT systems in organisations. The individually perceived level of control could be an intervening variable in the relationship between digitalisation anxiety and different behavioural outcomes.

However, our results also showed that about $50 \%$ of interviewees felt optimistic about digitalisation. In this vein, theorizing about (triggers of) digitalisation anxiety should also consider resources related to digitalisation, in the sense of "digitalisation optimism".

\subsection{Practical implications}

Organisations should carefully consider employees' concerns when planning and implementing new digital technologies. Based on our results, we propose interventions on different levels to prevent or reduce the occurrence of digitalisation anxiety and to further improve employees' feelings towards digitalisation. Societal triggers can be dealt with on a political and legislative level, organisational triggers must be dealt with on an upper management level, and individual triggers can be addressed by individuals and their supervisors. Table 2 provides an overview of potential interventions structured according to their initiator and the level of triggers they address. These interventions ei- 
Table 2 Overview of possible interventions against digitalisation anxiety

\begin{tabular}{|c|c|c|c|}
\hline Initiator & Societal triggers & Organisational triggers & Individual triggers \\
\hline $\begin{array}{l}\text { Society/ } \\
\text { Public }\end{array}$ & $\begin{array}{l}\text { Social exclusion } \\
\text { - Ensuring participation possibilities for } \\
\text { digitalisation (especially for older people) } \\
\text { - Offering public trainings or IT helpdesks } \\
\text { - Offering public Wifi to facilitate internet } \\
\text { access } \\
\text { - Expanding the distribution of high-speed } \\
\text { internet for mobile phones } \\
\text { Surveillance and data usage } \\
\text { - Prohibiting or restricting surveillance } \\
\text { - Ensuring data security through legal regu- } \\
\text { lations for data ownership } \\
\text { - Establishing punishments in the case of } \\
\text { violations } \\
\text { Job insecurity } \\
\text { - Introducing/fostering social welfare pro- } \\
\text { grams to provide security in the case of job } \\
\text { loss } \\
\text { Consequences of digitalisation: New forms of } \\
\text { work } \\
\text { - Ensuring humanity of new forms of work } \\
\text { through corresponding legal regulations }\end{array}$ & $\begin{array}{l}\text { Organisational expectations } \\
\text { - Creating legal regulations to restrict } \\
\text { blurring boundaries of work (CJEU } \\
\text { decision about the necessity of tracking } \\
\text { one's working hours even when working } \\
\text { from home) } \\
\text { Technical issues } \\
\text { - Establishing a functioning infrastructure } \\
\text { that allows organisations to be intercon- } \\
\text { nected in a technically safe way }\end{array}$ & - \\
\hline Organisation & $\begin{array}{l}\text { Surveillance and data usage } \\
\text { - Investing in IT security to ensure the safety } \\
\text { of employees' data } \\
\text { Unpredictability of developments and stress- } \\
\text { ful process } \\
\text { - Influencing and structuring introduction } \\
\text { process of new technologies/applications } \\
\text { in an employee-friendly way that takes into } \\
\text { account possible anxiety triggers } \\
\text { - Communication of planned changes (What } \\
\text { will change? When will it happen? What } \\
\text { consequences will it have for employees?) } \\
\text { Consequences of digitalisation } \\
\text { - Development of new concepts of work } \\
\text { - Providing formats to foster the develop- } \\
\text { ment of innovative ideas, e.g. creating } \\
\text { focus groups or providing a forum for ideas } \\
\text { and offering incentives for employees to } \\
\text { participate in organisational development }\end{array}$ & $\begin{array}{l}\text { Organisational expectations } \\
\text { - Organisational supports such as flexibil- } \\
\text { ity with regard to location and time of } \\
\text { work } \\
\text { - Clarifying expectations regarding em- } \\
\text { ployees' temporal availability } \\
\text { - Ensuring compliance with work regula- } \\
\text { tions (maximum hours of work per day, } \\
\text { rest times, etc.) } \\
\text { - Respecting ergonomic aspects of home } \\
\text { office workspaces } \\
\text { Organisational structure } \\
\text { - Providing new technology and ensuring } \\
\text { support for it } \\
\text { - Offering a competent helpdesk } \\
\text { - Offering leadership trainings } \\
\text { - Making use of more flexible hierarchies } \\
\text { Technical issues } \\
\text { - Investing in IT security to avoid hacker } \\
\text { attacks } \\
\text { - Providing new technology, keeping it up } \\
\text { to date, and ensuring support for it }\end{array}$ & $\begin{array}{l}\text { Personal development } \\
\text { - Offering trainings to sup- } \\
\text { port individual learning } \\
\text { needs (taking into ac- } \\
\text { count employees' time } \\
\text { constraints, reducing train- } \\
\text { ing time to an appropriate } \\
\text { level) } \\
\text { - Offering a competent } \\
\text { helpdesk } \\
\text { Changes in work } \\
\text { - Establishing organisational } \\
\text { supports to help employees } \\
\text { cope with higher demands } \\
\text { and increase their flexibility }\end{array}$ \\
\hline Team & - & $\begin{array}{l}\text { Organisational expectations } \\
\text { - Establishing team rules on expectations } \\
\text { regarding availability, etc }\end{array}$ & $\begin{array}{l}\text { Communication problems } \\
\text { - Establishing communi- } \\
\text { cation rules (e.g., Who } \\
\text { needs to be included on cc? } \\
\text { Who is expected to react to } \\
\text { emails? When are different } \\
\text { communication channels } \\
\text { appropriate? What possi- } \\
\text { ble problems might arise } \\
\text { when using indirect forms } \\
\text { of communication?) }\end{array}$ \\
\hline
\end{tabular}


Table 2 (Continued)

\begin{tabular}{|c|c|c|c|}
\hline Initiator & Societal triggers & Organisational triggers & Individual triggers \\
\hline Individual & $\begin{array}{l}\text { Consequences of digitalisation } \\
\text { - Participation in organisational programs to } \\
\text { foster innovation and create new business } \\
\text { opportunities } \\
\text { Stressful process } \\
\text { - Relying on the adaptation effect (some- } \\
\text { times it is necessary to just keep persever- } \\
\text { ing) }\end{array}$ & $\begin{array}{l}\text { Organisational expectations } \\
\text { - Setting boundaries for one's own work } \\
\text { (e.g., only working from a specific desk } \\
\text { at home and trying to set limits to work- } \\
\text { ing hours, switching off one's mobile } \\
\text { phone) }\end{array}$ & $\begin{array}{l}\text { Personal development } \\
\text { - Taking part in organisa- } \\
\text { tional trainings (if available } \\
\text { and relevant) } \\
\text { - Trainings outside the or- } \\
\text { ganisation (e.g., how to } \\
\text { structure emails effectively) } \\
\text { - Proactively requesting spe- } \\
\text { cific workshops or trainings } \\
\text { at work } \\
\text { Changes in work } \\
\text { - Structuring working day in } \\
\text { an efficient way that pre- } \\
\text { vents distractions from new } \\
\text { technologies and informa- } \\
\text { tion overload (e.g., setting } \\
\text { specific times for checking } \\
\text { emails (and not continu- } \\
\text { ously doing so)) }\end{array}$ \\
\hline
\end{tabular}

ther (1) emphasize the positive aspects of digitalisation, (2) decrease negative triggers of digitalisation anxiety, or (3) provide support for employees in coping with negative triggers and increase their resources. Some examples will be further illustrated in the following section.

Interventions on the societal level. Providing opportunities for participation in digital changes (e.g., offer public trainings or IT helpdesks) can be one way to prevent social exclusion. Moreover, laws to regulate new forms of work could help ensure that they do not lose sight of the human element. The Court of Justice of the European Union (2019) has already ruled on the necessity of tracking one's working hours even when working from home. Such tracking should be incorporated into national laws.

Interventions on the organisational level. Flexibility with regard to the location and time of work can help employees come to grips with the perceived loss of control resulting from automatized processes. At the same time, organisations need to clarify their expectations with regard to employees' temporal availability and ensure their compliance with relevant legal regulations (maximum working hours per day, etc.) to avoid blurring the boundaries of work. In teams, communication rules regarding digital media should be established (e.g., Who needs to be included in cc? Who is expected to react to emails? When are different communication channels appropriate? What problems can potentially arise when using indirect forms of communication?).

Interventions on the individual level. Employees' individual learning needs can be satisfied by taking part in either organisational trainings or external workshops. Set- ting boundaries with respect to work (e.g., working only from a specific desk at home, limiting one's working hours, switching off one's mobile phone after work) could be beneficial to facilitate detachment and recovery from work. Especially when combined with organisational interventions to clarify communication rules and expectations, such measures could help employees regain a feeling of control over their work.

In conclusion, practical interventions should be directed towards reducing employees' uncertainty or insecurity regarding digitalisation, which should in turn lead to a reduction of digitalisation anxiety. As our data showed, employees seem to be aware of digitalisation's opportunities and also see its positive aspects (e.g., for facilitating work, higher flexibility regarding the time and location of work). This generally optimistic view can be seen as a starting point for practical interventions.

\subsection{Limitations and future research}

Future research should quantitatively examine how the triggers identified in our study actually cause digitalisation anxiety and test whether uncertainty and lack of control statistically mediate this effect. As a first step towards achieving this, an instrument to measure triggers of digitalisation anxiety must be developed, which can be based on the qualitative findings of this study (see Pfaffinger et al. (2019) for a preliminary approach to measuring digitalisation anxiety). Furthermore, a digitalisation anxiety scale would enable practitioners and researchers to measure individuals' levels of digitalisation anxiety, compare it across organisations, industries, and cultures, and make ongoing changes more visible. The scale could also be used to further investigate 
behavioural consequences of digitalisation anxiety and its role in the stress process. Knowing more about underlying mechanisms of effect of digitalisation anxiety on behaviour and stress could also further inform interventions aiming at designing the digitalisation and the related changes in a humane way.

A rather high number of interviewers were involved in the data collection, which might have led to differences in how the interviews were conducted. However, we tried to avoid biases by making all interviewers familiar with the rules for conducting interviews. Moreover, the interviews were conducted in different languages and participants stemmed from different cultural backgrounds. We did not analyse potential cultural differences due to the limited sample size. However, we want to encourage future research to delve deeper into cross-cultural studies on digitalisation anxiety, as there are differences in digital readiness between countries (Cisco 2018).

Future research should also address how people react to more recent technologies such as artificial intelligence, robotics, the internet of things or virtual reality (Statista 2019), which might have even more profound implications for our lives and which are associated with higher levels of insecurity (in our study, employees mostly referred to e-mail or chat tools). Finally, in order to complete the picture regarding feelings towards digitalisation, future research should focus on positive feelings towards digitalisation, which could serve as resources that help to increase feelings of certainty and control.

Acknowledgements We thank Tobias Witte and also our project partners for their contribution in conducting the interviews, and Keri Hartman for proofreading our manuscript.

Funding The manuscript was written while the second author received a grant from the Bayerische Gleichstellungsfoerderung.

Funding Open Access funding provided by Projekt DEAL.

Open Access This article is licensed under a Creative Commons Attribution 4.0 International License, which permits use, sharing, adaptation, distribution and reproduction in any medium or format, as long as you give appropriate credit to the original author(s) and the source, provide a link to the Creative Commons licence, and indicate if changes were made. The images or other third party material in this article are included in the article's Creative Commons licence, unless indicated otherwise in a credit line to the material. If material is not included in the article's Creative Commons licence and your intended use is not permitted by statutory regulation or exceeds the permitted use, you will need to obtain permission directly from the copyright holder. To view a copy of this licence, visit http://creativecommons.org/licenses/by/4. $0 /$.

\section{References}

Althaus, M.P., Da Silva Matos, I., Dutschmann, J., Sharma, A.-M., \& Wilken, O. (2018). The digital economy in Germany issue
2018/2019. Berlin: Germany trade and invest. https://www.gtai. de/GTAI/Content/EN/Invest/_SharedDocs/Downloads/GTAI/ Fact-sheets/Business-services-ict/fact- sheet-digital-en.pdf?v=3. Accessed 22 Jan 2020.

Benevolo, C., Dameri, R.P., \& D’Auria, B. (2016). Smart mobility in smart city. In T. Torre, A. M. Craccini \& R. Spinelli (Eds.), Empowering organizations-enabling platforms and artefacts (pp. 13-28). Cham: Springer. https://doi.org/10.1007/978-3-31923784-8_2.

Berger, R., Romeo, M., Gidion, G., \& Poyato, L. (2016). Media use and technostress. In L. Gómez Chova, A. López Martínez \& I. Candel Torres (Eds.), INTED 2016 proceedings. 10th International Technology, Education and Development Conference. Valencia: IATED Academy.

Brod, C. (1984). Technostress: the human cost of the computer revolution. Reading: Addison-Wesley.

Cambre, M.A., \& Cook, D.L. (1985). Computer anxiety: definition, measurement, and correlates. Journal of Educational Computing Research, 1, 37-54. https://doi.org/10.2190/FK5L-092H-T6YBPYBA.

Cisco (2018). So gut ist Deutschland auf die Digitalisierung vorbereitet - Cisco Digital Readiness Index [That is how good Germany is prepared for digitalisation-Cisco Digital Readiness Index]. https://www.cisco.com/c/dam/global/de_de/solutions/ digital-transformation/deutschland/digital_readiness_index_web. pdf?ccid=cc000783\&oid=rptxa015960. Accessed 22 Jan 2020.

Court of Justice of the European Union. (ECJ) (2019). Federación de Servicios de Comisiones Obreras vs. Deutsche Bank SAE. C-55/18.

Federal Ministry for Economic Affairs and Energy (2018). Monitoring-Report Wirtschaft DIGITAL 2018 [Monitoring-Report Economy DIGITAL 2018]. https://www.bmwi.de/Redaktion/ DE/Publikationen/Digitale-Welt/monitoring-report-wirtschaftdigital-2018-langfassung.pdf?_blob=publicationFile\&v=4. Accessed 22 Jan 2020.

Federal Ministry of Health (2018). Glossary E-health. https://www. bundesgesundheitsministerium.de/service/begriffe-von-a-z/e/ehealth.html\#c1494. Accessed 22 Jan 2020.

Gray, J., \& Rumpe, B. (2015). Models for digitalization. Software and Systems Modeling, 14, 1319-1320. https://doi.org/10.1007/ s10270-015-0494-9.

Heerey, E. A., \& Kring, A. M. (2007). Interpersonal consequences of social anxiety. Journal of Abnormal Psychology, 116, 125-134. https://doi.org/10.1037/0021-843X.116.1.125.

Karasek, R. A. (1979). Job demands, job decision latitude, and mental strain: implications for job redesign. Administrative Science Quarterly, 24, 285-308. https://doi.org/10.2307/2392498.

Karasek, R.A. (2011). Demand/control model: A social, emotional, and physiological approach to stress risk and active behavior development. Geneva: International Labor Organization. http://www.iloencyclopaedia.org/part-v-77965/psychosocialand-organizational-factors. Accessed 22 Jan 2020.

Kirchner, S. (2019). Zeit für ein Update. Was die Menschen in Deutschland über Digitalisierung denken [Time for an update. What people in Germany think about digitalisation]. https://www. fes.de/umfrage-digitalisierung-in-deutschland. Accessed 22 Jan 2020.

Kuckartz, U., Dresing, T., Rädiker, S., \& Stefer, C. (2008). Qualitative Evaluation in sieben Schritten [Qualitative evaluation in seven steps]. In Qualitative Evaluation: Der Einstieg in die Praxis [Qualitative evaluation: the introduction in practice] (2nd edn., pp. 15-57). Wiesbaden: VS.

Kummer, T.F., Recker, J., \& Bick, M. (2017). Technology-induced anxiety: manifestations, cultural influences, and its effect on the adoption of sensor-based technology in German and Australian hospitals. Information \& Management, 54, 73-89. https://doi.org/ 10.1016/j.im.2016.04.002. 
Marcoulides, G. A. (1988). The relationship between computer anxiety and computer achievement. Journal of Educational Computing Research, 4, 151-158. https://doi.org/10.2190/J5N4-24HK$567 \mathrm{~V}-\mathrm{AT} 6 \mathrm{E}$.

Marks, M.L., \& Mirvis, P.H. (1997). Revisiting the merger syndrome: dealing with stress. Mergers and Acquisitions, 31(6), 21-27.

May, R. (1950). The meaning of anxiety. New York: Ronald Press.

Mayring, P., \& Fenzl, T. (2014). Qualitative Inhaltsanalyse [Qualitative content analysis]. In N. Baur \& J. Blasius (Eds.), Handbuch Methoden der empirischen Sozialforschung [Handbook methods of empirical social research] (pp. 543-556). Wiesbaden: Springer. https://doi.org/10.1007/978-3-531-18939-0_38.

Meuter, M.L., Bitner, M.J., Ostrom, A.L., \& Brown, S.W. (2005). Choosing among alternative service delivery modes: an investigation of customer trial of self-service technologies. Journal of Marketing, 69, 61-83. https://doi.org/10.1509/jmkg.69.2.61.60759.

Osiceanu, M.E. (2015). Psychological implications of modern technologies: "Technofobia" versus "technophilia". Procedia-Social and Behavioral Sciences, 180, 1137-1144. https://doi.org/10. 1016/j.sbspro.2015.02.229.

Pfaffinger, K. F., Huber, A. K., Reif, A. M., \& Spieß, E. (2019). Development and test of a new scale for the measurement of digital anxiety. Poster presented at the WASAD Congress, Würzburg.

PricewaterhouseCoopers LLP (2018). Will robots really steal our jobs? https://www.pwc.com/hu/hu/kiadvanyok/assets/pdf/impact_of_ automation_on_jobs.pdf. Accessed 22 Jan 2020.

Ragu-Nathan, T. S., Tarafdar, M., Ragu-Nathan, B. S., \& Tu, Q. (2008). The consequences of technostress for end users in organizations: conceptual development and empirical validation. Information Systems Research, 19, 417-433. https://doi.org/10.1287/isre. 1070.0165 .

Raub, A.C. (1981). Correlates of computer anxiety in college students (doctoral dissertation). Philadelphia: University of Pennsylvania.

Robinson, O.C. (2014). Sampling in interview-based qualitative research: a theoretical and practical guide. Qualitative Research in Psychology, 11, 25-41. https://doi.org/10.1080/14780887.2013. 801543.

Salanova, M., Llorens, S., \& Cifre, E. (2013). The dark face of technologies: about the concept and measurement of technostress experience. International Journal of Psychology, 48, 422-433. https://doi.org/10.1080/00207594.2013.680460.

Salanova, M., Llorens, S., \& Ventura, M. (2014). Technostress: the dark side of technologies. In C. Korunka \& P. Hoonakker (Eds.), The impact of ICT on quality of working life (pp. 87-103). Dordrecht: Springer. https://doi.org/10.1007/978-94-017-8854-0.

Salanova, M., Llorens, S., Cifre, E., \& Nogareda, C. (2007). El tecnoestrés: concepto, medida e intervención psicosocial [Technostress: Concept, measurement and psychosocial intervention]. Nota técnica de prevención, 730. http://www.want.uji. es/download/el-tecnoestres-concepto-medida-e-intervencionpsicosocial/. Accessed 22 Jan 2020.

Sandelowski, M. (1995). Sample size in qualitative research. Nursing \& Health, 18, 179-183. https://doi.org/10.1002/nur.4770180211.

Smith, J.A., Flowers, P., \& Larkin, M. (2009). Interpretative phenomenological analysis: theory, method and research. London: SAGE.

Statista (2019). In-depth: industry 4.0 2019—Statista digital market outlook. https://de.statista.com/statistik/studie/id/67366/dokument/ in-depth-industry-40/. Accessed 22 Jan 2020.

Tarafdar, M., Tu, Q., Ragu-Nathan, B. S., \& Ragu-Nathan, T. S. (2007). The impact of technostress on role stress and productivity. Journal of Management Information Systems, 24, 301-328. https://doi. org/10.2753/MIS0742-1222240109.

Torkzadeh, G., \& Angulo, I.E. (1992). The concept and correlates of computer anxiety. Behaviour \& Information Technology, 11, 99-108. https://doi.org/10.1080/01449299208924324.

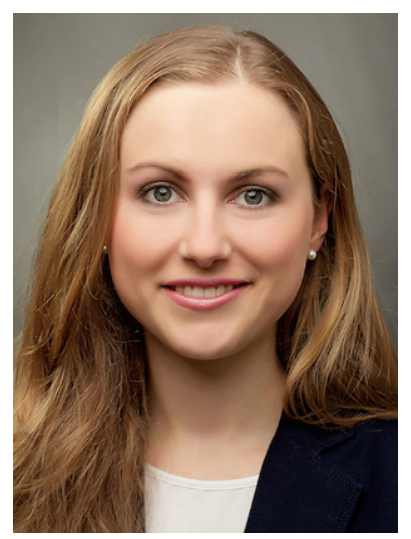

Katharina F. Pfaffinger ist Mitarbeiterin am Lehrstuhl Wirtschaftsund Organisationspsychologie der Ludwig-Maximilians-Universität München. Sie promoviert zum Thema „Neue Stressfaktoren durch die Digitalisierung und Interventionsmöglichkeiten" und forscht im Bereich Gesundheit und Wohlbefinden am Arbeitsplatz.

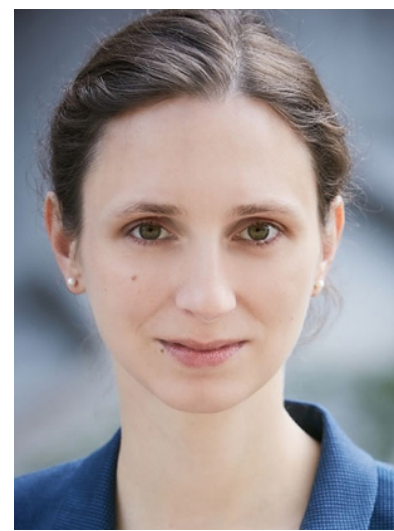

Dr. Julia A.M. Reif ist Mitarbeiterin am Lehrstuhl Wirtschaftsund Organisationspsychologie der Ludwig-Maximilians-Universität München. Sie forscht und publiziert zu den Themen Verhandlungen und Verhandlungsinitiierung, Teamprozesse, Beziehungsregulierung in ökonomischen Entscheidungssituationen, organisationale Akkulturation und Gesundheit in Organisationen.

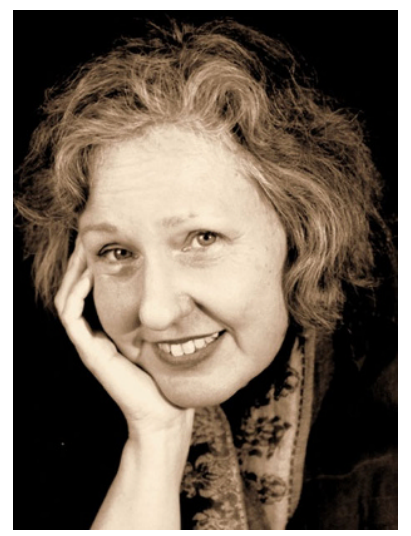

Apl. Prof. Dr. Erika Spieß ist Mitarbeiterin am Lehrstuhl Wirtschaftsund Organisationspsychologie der Ludwig-Maximilians-Universität München. Sie forscht und publiziert zu den Themen Kooperation in Organisationen, interkulturelles Handeln in wirtschaftsnahen Kontexten und Gesundheit in Organisationen sowie Konsumentenpsychologie. 


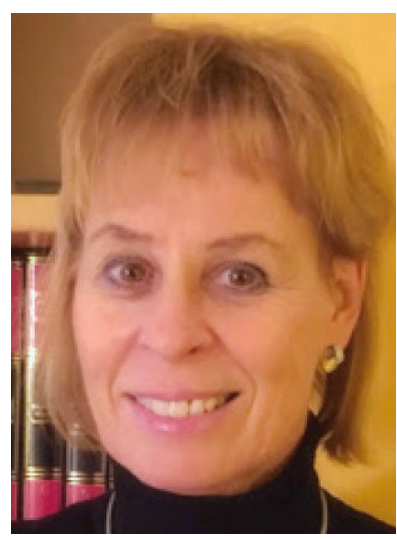

Dr. Rita Berger ist Professorin an der Fakultät für Psychologie der Universität Barcelona im Bereich Arbeits- und Organisationspsychologie. Sie forscht und publiziert vor allem zu den Themen Interkulturelle Führung, Teams und Gesundheit in Organisationen. 